\title{
PENDIDIKAN KARAKTER DALAM ISLAM \\ Pemikiran Al-Ghazali tentang Pendidikan Karakter Anak \\ Berbasis Akhlaq al-Karimah
}

\begin{abstract}
Syamsul Kurniawan

Dosen Fakultas Tarbiyah dan Ilmu Keguruan Institut Agama Islam Negeri (IAIN) Pontianak

It is the study on Al-Ghazali views of education about character education of children based moral character. According to the view, the character must be built since they were in early age. Hopefully, they know the difference between good and bad manners, and can determine their character (whether it is good or bad). The character education based moral character is aimed to form the positive character which leads to selfapproach to God, in order to gain the happiness in the world and the hereafter.
\end{abstract}

Key words: Children, Character education, Moral Character 


\section{PENDAHULUAN}

Agama dan akhlak, merupakan dua hal yang saling berkaitan dan tidak dapat dipisahkan. Sebab, kualitas keberagamaan seseorang ukurannya adalah akhlaqnya. Akhlaq merupakan sebuah pilar penting dalam agama Islam. Semua aspek ajaran Islam mustahil terlaksana dengan baik tanpa adanya akhlak yang baik. Akhlaq al-karimah adalah pertanda kematangan iman serta merupakan kunci kesuksesan hidup di dunia dan akhirat.

Hal ini sejalan dengan misi Rasulullah Saw menyampaikan ajaran Islam yaitu menyempurnakan akhlaq umat. Beliau bersabda: "Aku diutus untuk menyempurnakan akhlak manusia." (HR. Ahmad dan Baihaqi). Berdasarkan hadits ini, pada dasarnya syariat yang dibawa Rasulullah Saw. bermuara pada pembentukan akhlak mulia (akhlaq al-karimah).

Dalam Islam, akhlaq merupakan dimensi nilai dari syariat Islam. Jika syariat berbicara tentang syarat rukun, sah atau tidak sah, maka akhlak menekankan pada kualitas dari perbuatan. Akhlaq merupakan salah satu dari ajaran Islam yang harus dimiliki oleh setiap muslim (Yoke Suryadarma dan Ahmad Hifdzil Haq, AtTa'dib, Volume 10, Nomor 2, Desember 2015, hlm. 362). Dengan demikian, perlu sekali umat Islam mempunyai kesadaran mengenai pentingnya pendidikan akhlaq. Sejak usia dini, anak-anak mesti dididik dengan baik sehingga berakhlaqul karimah.

Saat ini, pendidikan karakter sedang menjadi 'trending topic' dalam dunia pendidikan. Gagasan pendidikan karakter yang sedang didegungkan pemerintah ini harusnya memiliki arah dan tujuannya yang jelas. Dengan arah yang jelas, implementasi di lapangan menjadi mudah dilaksanakan. Sebaliknya bila tidak jelas, maka jangankan hasil dari proses pendidikan tersebut, implementasinya saja mengalami banyak kendala. Karena itu memahami pendidikan karakter khususnya dalam Islam menjadi penting.

Istilah karakter yang dalam bahasa Inggris, character berasal dari istilah Yunani yaitu charassein yang berarti membuat tajam atau membuat dalam (John. M. Echols dan Hassan Shadily, 2006; Lorens Bagus, 2005: 392). Karakter juga berarti mengukir. Sifat utama ukiran adalah melekat kuat pada benda yang diukir. Karenanya, karakter adalah sebutan untuk ciri khas seseorang. Karakter sendiri tidak dapat dilepaskan dari konteks sosial budaya, di mana karakter disadari 
sangat dipengaruhi oleh lingkungan sosial budaya tertentu (Syamsul Kurniawan, 2013: 28). Dalam Islam, karakter lebih dikenal dengan istilah akhlaq.

Karena itu, pendidikan karakter dalam Islam merupakan sebuah proses membentuk akhlak, kepribadian dan watak yang baik, yang bertanggung jawab akan tugas yang diberikan Allah kepadanya di dunia, serta mampu menjalankan perintah-Nya dan menjauhi larangan-Nya. Karena itu dalam Islam, pendidikan karakter sama maknanya dengan pendidikan agama yang berbasis akhlak. Islam melihat pentingnya membentuk pribadi muslim yang berakhlaq mulia (akhlaq alkarimah).

Kaitannya dengan merancang model pendidikan bisa mengacu pada konsepkonsep pendidikan yang lahir dari hasil sintesis, adaptasi, dialog keilmuan, ilmuisasi, dan bahkan islamisasi nilai-nilai pendidikan. Upaya menginterpretasi konsep pendidikan Islam dapat diawali dengan kajian tokoh dan pemikiran pendidikannya. Kajian tentang pemikiran pendidikan seorang tokoh menjadi penting, terutama untuk memperoleh gambaran tentang persepsi seorang tokoh, pemikiran yang digelutinya, keberhasilan pemikirannya, serta hikmah dari pemikirannya. (Arief Furchan dan Agus Maimun, 2005: 9). Di antara tokoh yang relevan dikaji pemikirannya dalam konteks pendidikan karakter anak berbasis akhlaq al-karimah adalah al-Ghazali.

Al-Ghazali merupakan tokoh yang sangat memerhatikan dunia pendidikan, karena menurutnya pendidikanlah yang banyak membentuk corak peradaban pada sebuah bangsa (Syamsul Kurniawan, At-Turats, Volume 3, Nomor 1, Desember, 2008, hlm. 23). Pemikiran pendidikan Al-Ghazali, sebagaimana pendapat alTibawi (1972: 39), dianggap sangat baik, sistematis, dan komprehensif, jika dibandingkan dengan tokoh-tokoh lain semasanya. Sebagai seorang pemikir, pemikiran pendidikan Al-Ghazali ikut mempengaruhi pemikiran-pemikiran pendidikan tokoh-tokoh setelahnya.

Pemikiran tentang pendidikan karakter yang marak diperbincangkan urgensitasnya pada abad ini, sesungguhnya telah lama diulas oleh Al-Ghazali melalui pemikiran-pemikiranya tentang akhlaq al-karimah. Pada konteks ini, pemikiran Al-Ghazali yang secara umum menekankan pentingnya akhlaq alkarimah dididikkan sejak usia dini, relevan secara konseptual dengan pemikiran 
tokoh-tokoh pendidikan abad ini yang menyuarakan pentingnya character building.

Athiyah al-Abrasy (dalam A. Syaefuddin, 2005: 109-110), berpendapat bahwa salah satu pesan/nasihat al-Ghazali yang penting adalah tentang pentingnya memerhatikan pendidikan anak-anak sejak usia dini. Karena, pendidikan yang baik pada anak-anak sejak usia dini akan menentukan bagaimana kelak kepribadian dari seorang anak. Dalam hal ini, al-Ghazali mewariskan sebuah pemikiran tentang bagaimana pendidikan akhlaq dan moral pada anak-anak seharusnya dirancang dan dilaksanakan dalam pendidikan Islam.

Tulisan ini mengkaji tentang pemikiran Al-Ghazali tentang pendidikan karakter anak berbasis akhlaq al-karimah. Tulisan ini merupakan kajian kepustakaan, dalam pengertian sumber data kajian ini berasal dari kepustakaan, baik berupa buku atau hasil penelitian.

\section{RIWAYAT HIDUP AL-GHAZALI}

Nama lengkapnya Abu Hamid Muhammad bin Muhammad bin Ta'us AthThusi Asy-Syafi‘iy, yang lebih dikenal dengan Al-Ghazali. Lahir di Gazaleh, sebuah desa di pinggiran Kota Thus, Kawasan Khurasan, Iran, pada tahun 450H/1058 M Karena kedudukannya yang tinggi di mata umat Islam, dia mendapat gelar Hujjat al-Islam (Abu Al-Wafa' Al-Ghanimi Al-Taftazani, 1974: 148).

Sejak kecil, al-Ghazali sudah mendalami fiqh. Al-Ghazali berguru kepada Ahmad ibn Muhammad al-Radzakani, kemudian ke Jurjan untuk menimba ilmu pada Imam Abu Nashr al-Ismaili. Setelah itu, al-Ghazali menetap di Thus untuk mengulang-ngulang pelajaran yang diperolehnya di Jurjan selama 3 tahun. Lalu berkunjung ke Naisabur dan berguru pada Imam Haramain, Abu al-Ma'ali alJuwaini di Madrasah Nizamiyah. Al-Ghazali juga memperdalam ilmu fikihnya, ushul fikih dan mantiq serta tasawuf pada Abu Ali al-Faramadhi (Ramayulis dan Samsul Nizar, 2009: 271).

Setelah wafatnya Imam Haramain dan al-Faramadhi, al-Ghazali berangkat ke Askar untuk memenuhi undangan diskusi yang diselenggarakan oleh Menteri Nizam al-Muluk dari Dinasti Saljuk. Di sana, ia disambut dengan penuh kehormatan sebagai ulama besar. Dalam perdebatan dengan para ulama dalam 
majelis tersebut, al-Ghazali mampu menunjukkan keluasan pengetahuannya. Karena kepintarannya, al-Ghazali diminta oleh Nizam al-Mulk untuk pindah ke Baghdad dan mengajar di Madrasah Nizamiyah. Pada usianya yang ke 34 alGhazali dianugerahkan jabatan sebagai guru besar di Madrasah Nizamiyah (A. Syaefuddin, 2005: 97-98).

Di tengah kesibukan al-Ghazali sebagai pengajar di Madrasah Nizamiyah, al-Ghazali tetap meluangkan waktunya untuk mendalami ilmu lain, seperti filsafat Yunani. Namun bukan berarti al-Ghazali tenggelam dalam berfilsafat, karena justru setelah mempelajari filsafat ia memilih jalan zuhud (Hasan Langgulung, 1980: 107-108).

Selanjutnya Al-Ghazali meninggalkan Baghdad dan menetap di Damsyik selama 2 tahun, lalu pindah ke Palestina, kemudian kembali ke Baghdad, dan akhirnya menetap di Thus. Selama itu aktifitas al-Ghazali sebatas merenung, membaca, menulis dan menjalani tasawuf di akhir masa hidupnya. Al-Ghazali kemudian kembali ke Naisabur dan mengajar di sana sampai akhir hayatnya (505 H/1111 M) (Ramayulis dan Samsul Nizar, 2009: 272).

\section{LATAR BELAKANG PEMIKIRAN AL-GHAZALI}

Pemikiran al-Ghazali dilatarbelakangi dengan munculnya berbagai aliran keagamaan dan trend-trend pemikiran pada masanya. Pada masanya, muncul beberapa tokoh pemikir besar seperti tokoh Syi'ah Abu 'Abdillah al-Baghdadi (w. 413 H.), tokoh Mu’tazilah al-Qadhi ‘Abd al-Jabbar (w. 415 H.), Abu ‘Ali Ibn Sina (w. 428 H.) seorang filosof, Ibn al-Haitam (w. 430 H.) seorang ahli Matematika dan Fisika, Ibn Hazm (w. 444 H.) seorang tokoh salafisme di Spanyol, alIsfara'ini (w. 418 H.) dan al-Juwaini (w. 478 H.) sebagai dua tokoh Asy’arisme, serta Hasan as-Sabbah (w. 485 H.) dari kalangan tokoh Batiniyah.

Al-Ghazali menggolongkan berbagai pemikiran pada masanya menjadi empat aliran populer, yaitu mutakallimun, para filosof, al-ta'lim dan para sufi. Dua aliran yang pertama adalah mencari kebenaran berdasarkan akal walaupun terdapat perbedaan yang besar dalam prinsip penggunaan akal antara keduanya. Golongan yang ketiga menekankan otoritas imam dan yang terakhir menggunakan intuisi (al-dzauq). 
Pergolakan pemikiran pada masanya sedikit banyak mempengaruhi kecenderungan pemikiran al-Ghazali semasa hidup. Al-Ghazali yang semula memiliki kecenderungan rasional yang sangat tinggi - Bisa dilihat dari karyakaryanya sebelum penyerangannya terhadap Filsafat - mengalami keraguan. Keraguan ini berpangkal dari adanya kesenjangan antara persepsi ideal dalam pandangannya dengan kenyataan yang sesungguhnya.

Menurut persepsi idealnya, kebenaran itu adalah satu sumber berasal dari alfithrah al-ashliyat. Sebab sebagaimana sebuah hadits, bahwa setiap anak dilahirkan atas dasar fithrahnya. Adapun yang membuat anak itu menjadi Yahudi, Nasrani, atau Majusi adalah kedua orangtuanya. Oleh karenanya ia mencari hakekat al-fithrah al-ashliyat yang berujung pada keraguan-keraguan sampai datangnya pengetahuan hakiki padanya. Dari sinilah al-Ghazali menyimpulkan bahwa ia harus mulai dari hakikat pengetahuan yang diyakini kebenarannya.

Bertolak dari pengetahuan yang selama ini ia kuasai, al-Ghazali menduga bahwa kebenaran hakikat diperoleh dari yang tergolong inderawi (al-hisriyat) dan yang bersifat apriori dan aksiomatis (al-dharuriyat). Sebab kedua pengetahuan ini bukan berasal dari orang lain tetapi dari dalam dirinya. Ketika ia mengujinya kemudian ia menyimpulkan bahwa kemampuan inderawi tidak lepas dari kemungkinan salah.

Kepercayaan al-Ghazali terhadap akal sebagaimana kecenderungan filsuf pada masanya,juga goncang karena tidak tahu apa yang menjadi dasar kepercayaan atas akal. Seperti pengetahuan aksiomatis yang bersifat apriori, begitupula akal. Ketika akal harus membuktikan sumber pengetahuan yang lebih tinggi, akal hanya sampai pada simpulan-simpulan yang hipotesis saja, dan tidak sampai pada pembuktian pengetahuan secara faktual.

Al-Ghazali kemudian menduga adanya pengetahuan suprarasional. Kemungkinan tersebut kemudian diperkuat adanya pengakuan para sufi, bahwa pada situasi-situasi tertentu (akhwal) mereka melihat hal-hal yang tidak sesuai dengan ukuran akal dan adanya hadis yang menyatakan bahwa manusia sadar (intabahu) dari tidurnya sesudah mati. Al-Ghazali menyimpulkan ada situasi normal di mana kesadaran manusia lebih tajam. Akhirnya pengembaraan intelektual al-Ghazali berakhir pada wilayah tasawuf dimana ia meyakini aldzauq (intuisi) lebih tinggi dan lebih dipercaya dari akal untuk menangkap 
pengetahuan yang betul-betul diyakini kebenarannya. Pengetahuan ini diperoleh melalui nur yang dilimpahkan Tuhan kedalam hati manusia. Pemikiran al-Ghazali tentang ini sedikit banyak dipengaruhi oleh pengetahuan-pengetahuannya di bidang filsafat. Demikian pula pandangan al-Ghazali tentang akhlaq al-karimah juga tidak terlepas dari pemikiran filosofisnya mengenai hal ini.

Al-Ghazali dikenal sebagai seorang ulama dan pemikir besar dalam dunia Islam yang sangat produktif dalam menulis. Di antara karyanya yang terkenal, yaitu Maqashid al-Falasifah, Tahafut al-Falasifah, Ihya' Ulumuddin, al-Munqidz min adh-Dhalal, al-Iqtishad fi al-I'tiqad, al-Mustashfa, Minhajul Abidin, Kimya' as-Sa'adah, al-Risalah al-Laduniyah, Misykat al-Anwar, Ayyuhal Walad, Adab al-Sufiah, Al-Adab fi ad-Din, al-Imla' an Asykali al-Ihya', Ihya' Ulumuddin, Bidayah al-Hidayah wa Tahdzib an-Nufuz bi al-Adab asy-Syar'iyah, Jawahir alQur'an wa Dauruh, al-Hikmah fii Makhluqat Allah, Khulasut al-Tasawuf, alRisalah Laduniyah, al-Risalah al-Wadziyah, Fatihat al-Ulum, Al-Kasyf wa alTabyin fii Gurur al-Haqlqi Ajmain, Al-Mursid al-Amin yaa Maudikat alMu'minin, Musykilat al-Anwar, Mizan al-Amal, dan masih banyak lagi yang lainnya (A. Syaefuddin, 2005: 100-102; M. Bahri Ghazali, 1996: 40-48).

\section{PEMIKIRAN AL-GHAZALI TENTANG AKHLAQ AL-KARIMAH DAN PENDIDIKAN KARAKTER ANAK BERBASIS AKHLAQ AL-KARIMAH Pemikiran Al-Ghazali Tentang Akhlaq Al-Karimah}

Secara bahasa, kata “al-akhlak"sebagai jamak dari “al-khuluq” memiliki banyak makna, yaitu ath-thabi'ah (Abu Abdirrahman al Khalil bin Ahmad alFarahidi, tth: 151), atau ath-thab'u (tabiat), ad Dîn (agama) dan as sajiyyah (perangai) (Muhammad bin Mukarram bin Manzhûr al Afriqi al Mishri, tth. Juz X: 85). Hakikat “al-khuluq”, kata Ibnu Manzhur, "dipergunakan untuk bentuk manusia yang tidak tampak yaitu jiwa, sifat-sifat dan makna-maknanya yang khusus berkaitan dengannya, sebagaimana al-khalqu yang dipergunakan untuk bentuk manusia yang tampak, sifat-sifat dan makna-maknanya. Keduanya samasama memiliki sifat baik dan jelek (hasanatun wa qabîhatun), balasan dan hukuman (ats tsawâb wal 'iqâb) di mana keduanya banyak berkaitan erat dengan sifat-sifat bentuk yang tidak tampak daripada sifat-sifat bentuk yang nampak.

Hal ini cukup beralasan, apalagi hadits-hadits Nabi Saw. juga mendukung 
asumsi ini. Hadits-hadits dimaksud seperti: "Sesungguhnya aku diutus untuk menyempurnakan akhlak yang mulia"; "Sesungguhnya yang paling banyak memasukkan manusia ke dalam surga adalah takwa kepada Allah dan akhlak yang baik"; "Orang mukmin yang paling sempurna imannya adalah orang yang paling baik akhlaknya."

Menurut istilah, akhlaq sebagaimana al-Ghazali, didefinisikan sebagai kondisi yang menetap di dalam jiwa, di mana semua perilaku bersumber darinya dengan penuh kemudahan tanpa memerlukan proses berpikir dan merenung. Apabila kondisi jiwanya menjadi sumber perbuatan-perbuatan yang baik lagi terpuji, baik secara akal dan syariat, maka kondisi itu disebut sebagai akhlak yang baik, dan apabila yang bersumber darinya adalah perbuatan-perbuatan yang jelek, maka kondisi itu disebut sebagai akhlak yang buruk (Abu Hamid Muhammad bin Muhammad al Ghazali, 2008: 57).

Inilah point penting yang ditekankan oleh al-Ghazali dalam mendefinisikan akhlak, yaitu kondisi di dalam jiwa yang merupakan sumber perilaku harus bersifat tetap (istiqamah). Definisi akhlaq yang dikeluarkan oleh al-Ghazali ini sejalan dengan pendapat Ibnu Miskawaih, al-Jahizh, dan Abdurrahman alMaidani. Ibnu Miskawaih (dalam Thâha Abdussalam Khudhair, 1997: 26) mendefinisikan akhlak sebagai kondisi jiwa yang mendorong untuk melakukannya tanpa berpikir dan merenung ( af'âlihâ min ghairi fikrin wa rawiyyatin). Al Jahizh (1989: 12) mendefinisikan akhlak dengan, "Kondisi jiwa dimana manusia melakukan perbuatanperbuatannya tanpa proses merenung dan memilih." (hâlun nafsi bihâ yaf'alul insanu af'âlahu bi lâ rawiyyatin wa lâ ikhtiyârin). Sementara Abdurrahman al Maidani (1979, Juz I: 7), mendefinisikannya sebagai, "sifat yang menetap di dalam jiwa, baik itu bawaan maupun diusahakan, yang memiliki pengaruh dalam perilaku, entah itu baik atau buruk." (Shifatun mustaqirratun fin nafsi fithriyyatan au muktasabatan dzâtu âtsârin fis sulûki mahmûdatan au madzmûmatan). Dalam hal ini, al-Ghazali mengklasifikasikan akhlak ke dalam dua bentuk, yaitu akhlaq yang baik (al khuluq al hasan), dan akhlaq yang buruk (al khuluq as sayyi').

Al-Ghazali mengatakan bahwa induk dan prinsip akhlak ada empat, yaitu al hikmah (kebijaksanaan), asy syaja'ah (keberanian), al iffah (penjagaan diri) dan al 'adl (keadilan). Kebijaksanaan adalah kondisi jiwa untuk memahami yang benar 
dari yang salah pada semua perilaku yang bersifat ikhtiar (pilihan); keadilan adalah kondisi dan kekuatan jiwa untuk menghadapi emosi dan syahwat serta menguasainya atas dasar kebijaksanaan. Juga mengendalikannya melalui proses penyaluran dan penahanan sesuai dengan kebutuhan; keberanian adalah ketaatan kekuatan emosi terhadap akal pada saat nekad atau menahan diri; dan penjagaan diri ('iffah) adalah terdidiknya daya syahwat dengan pendidikan akal dan syariat. Maka, dari normalitas keempat prinsip ini muncul semua akhlak yang terpuji." (Abu Hamid Muhammad bin Muhammad al Ghazali, 2008, Juz III: 58).

\section{Pendidikan Karakter Anak Berbasis Akhlaq Al-Karimah}

Al Ghazali menolak pendapat yang mengasumsikan akhlak sebgai sesuatu yang tidak dapat berubah. Karena jika demikian halnya, maka wasiat, nasihat, dan pendidikan tidaklah berarti apa-apa. Sementara Nabi Saw, bersabda, "perbaikilah akhlak-akhlak kalian" (hassinû akhlâqakum).

Di sinilah letak pentingnya pendidikan akhlaq. Menurut al-Ghazali, akhlak dapat diperoleh dan dibentuk melalui pendidikan. Sekalipun al Ghazali tidak memungkiri adanya pengaruh bawaan yang mempengaruhi akhlaq seseorang sebagaimana teori nativisme (Abu Hamid Muhammad bin Muhammad al Ghazali, 2008, Juz III: 61). Pendidikan akhlaq perlu diberikan sejak usia dini, sehingga seorang anak paling tidak mengetahui, apa yang dikatakan al-Ghazali (1960: 204) sebagai perbuatan baik dan buruk, sanggup untuk melakukannya, serta dapat menilai kondisi atau keadaan akhlaqnya (apakah baik atau buruk).

Pemikiran al-Ghazali tentang pendidikan karakter berbasis akhlaq alkarimah bisa dibaca, di antaranya melalui ulasan-ulasannya dalam Kitab Ayyuhal Walad (2005). Konsep al-Ghazali pada kitab ini, berpangkal pada empat hal: pertama, pendidikan hendaknya berangkat dari titik awal tujuan pengutusan Rasulullah Saw, yakni untuk menyempurnakan akhlaq. Sehingga bentuk, materi, serta tujuan pendidikan dirancang agar terbentuk kepribadian seseorang yang berakhlaq mulia; kedua, kurikulum pendidikan mesti mampu mengoptimalkan potensi-potensi yang ada pada seorang anak; ketiga, pendidikan akhlaq adalah pendidikan integratif yang memerlukan kerjasama yang edukatif; keempat, sifat pendidikan akhlaq yang menyentuh dimensi spiritual anak yang dididik. 
Pendidikan semestinya dapat mengarah pada realisasi tujuan keagamaan dan perbaikan karakter atau akhlaq, yang berangkat dari niatan bertaqarrub (mendekatkan diri) kepada Allah. Rumusan tujuan pendidikan ini disandarkan pada QS adz-Dzariyat ayat 56: "Dan Aku tidak menciptakan jin dan manusia melainkan supaya mereka mengabdi kepada-Ku”. Juga sesuai dengan sabda Rasulullah Saw: "Sesungguhnya saya diutus hanya untuk menyempurnakan kemuliaan akhlak manusia”.

Tujuan pendidikan sebagaimana pendapat al-Ghazali di atas, menurut Ramayulis dan Samsul Nizar (2009: 273) dipengaruhi oleh ilmu tasawuf yang belakangan dikuasainya. Bagi al-Ghazali, seorang anak mesti dapat dididik sehingga menggunakan dunia untuk tujuan akhirat. Bukan berarti al-Ghazali menepikan urusan dunia, melainkan menjadikan dunia sebagai alat untuk mencapai tujuan akhirat. Al-Ghazali mengasumsikan dunia sebagai ladang akhirat, karena menurutnya dunia ini dapat berfungsi sebagai sarana yang mengantarkan kepada Allah (Al-Ghazali dalam Muhammad Jawwad Ridha, 1980: 25).

Apa yang dikemukakan al-Ghazali ini, terutama agar seorang anak menjadi manusia yang paripurna yang tahu kewajibannya sebagai hamba Allah maupun pada sesama manusia. Hal ini misalnya terlihat dalam nasihat yang diberikan alGhazali sebagaimana dalam kitab Ayyuhal Walad (2005) seperti: pertama, pentingnya seorang anak mendekatkan diri kepada Allah; kedua, seorang anak bergaul dengan sesama secara santun, ramah, dan mawas diri; ketiga, seorang anak hendaknya menuntut ilmu yang bermanfaat terutama yang dapat memperbaiki keadaan hati dan membersihkan jiwa; keempat, agar seorang anak tidak tamak terhadap harta benda, kecuali sekadar mencukupinya."

Dalam belajar, seorang anak perlu mendapat penjelasan yang bersandar dari dalil naqliyah dan aqliyah. Dalil naqliyah adalah dalil yang diambil dari Alquran dan Assunnah, sementara dalil aqliyah adalah penjelasan rasional. Pada konteks ini, penjelasan rasional mestilah juga mengantarkan pada sebuah tujuan atau orientasi akhir (final goal), yaitu mengantarkan seorang anak dekat dengan Allah SWT (Syamsul Kurniawan, At-Turats, Volume 3, Nomor 1, Desember, 2008, hlm. 25). 
Tujuan seorang anak dalam menuntut ilmu mesti diluruskan, yaitu untuk memperoleh ilmu yang bermanfaat. Ilmu yang bermanfaat adalah ilmu yang dapat diamalkan dalam kehidupan sehari-hari. Al-Ghazali sebagaimana dikutip Fathiyah Hasan (1964: 15), mengatakan: "Semua manusia itu celaka, kecuali orang yang berilmu. Semua orang itu celaka, kecuali orang yang mengamalkan ilmunya. Semua orang yang beramal itu celaka, kecuali orang yang ikhlas dalam mengamalkan ilmunya."

Dalam kitabnya, Ayyuhal Walad (1968), Al-Ghazali mengatakan:

Wahai anakku! Janganlah kamu miskin amal. Yakinlah sesungguhnya ilmu yang tidak diamalkan tidak akan memberikan manfaat apa-apa bagi para pemiliknya. Semisal ada seorang laki-laki yang menggenggam sepuluh bilah pedang India (pedang yang terkenal ketajamannya) dan menggenggam senjata yang lain. Tambahan lagi ia juga seorang laki-laki yang gagah berani dan ahli perang. Kemudian dia diserang seekor harimau yang menakutkan dan besar.

Apa yang terjadi menurut penilaianmu? Mungkinkah puluhan senjata tadi bisa mengamankan sang laki-laki tadi dari terkaman harimau, jika ia tidak menggunakan atau tidak mengayunkan senjatanya? Hasilnya dapat diketahui, senjata tersebut tidak akan menyelamatkan pemiliknya dari bahaya kecuali ia mengayunkan atau memukulnya.

Demikian pula dengan seorang pelajar yang membaca seratus ribu persoalan ilmiah tetapi tidak mengamalkannya, maka ilmu itu tidak akan pernah bermanfaat kecuali ia mengamalkannya.

Pendidikan karakter berbasis akhlaq al-karimah perlu diberikan pada anakanak sejak usia dini. Hal ini karena hasil dari sebuah proses pendidikan tidak selalu didapat secara instant. Apalagi hasil dari pendidikan karakter anak berbasis akhlaq al-karimah amat bergantung dari banyak faktor.

Dikatakan al-Ghazali, "mendidik anak ibarat mengukir di atas batu”. Hal ini sejalan dengan pengertian karakter menurut kebahasaan yang berasal dari bahasa Yunani, charassein, yang berarti menggoreskan pada lilin, batuan dan logam (Syamsul Kurniawan, At-Turats, Volume 6, Nomor 1, Desember 2012, hlm. 18). Anak, sebagaimana pendapat al-Ghazali, ibarat kertas kosong, yang menerima apapun yang dibuat padanya. Hal ini agaknya merupakan interpretasi beliau atas 
sabda Nabi Muhammad Saw, "Setiap anak yang lahir dalam keadaan fitrah, maka ayah dan ibunyalah yang menjadikannya Yahudi, Nasrani, atau Majusi”. Pendapat al-Ghazali ini sejalan dengan pendapat pemikir berikutnya setelah 13 abad kemudian yaitu John Locke yang mengenalkan empirisme dan teori tabularasa. Sebagaimana al-Ghazali, John Locke juga mengasumsikan anak yang lahir sebagaimana meja lilin yang bersih (tabularasa). Perkembangan anak menurut Locke amat ditentukan oleh lingkungan pendidikannya (M. Arifin, 1991: 25; Syamsul Kurniawan, 2016: 71).

Dalam mendidik anak, al-Ghazali sebagaimana dikutip Abuddin Nata (1997: 163-164) menjelaskan seseorang hendaknya: pertama, mencintai anakanak yang ia didik; kedua, tidak beorientasi pada sebatas keuntungan materi; ketiga, menyadari bahwa tujuan utama mengajari anak-anak adalah terbentuknya kepribadian mereka dengan baik, dan menjadi pribadi yang mampu mengamalkan ilmu-ilmu yang telah mereka terima; keempat, selalu mengingatkan pada anakanak yang dididik, bahwa tujuan menuntut ilmu bukanlah untuk mengejar kebanggaan diri atau sebatas mengejar keuntungan pribadi, melainkan karena Allah; kelima, mendorong anak-anak yang dididik agar mencari ilmu yang bermanfaat, yaitu ilmu yang kelak akan mengantarkan mereka kepada kebahagiaan dunia dan akhirat; keenam, memberikan contoh dan teladan yang baik, seperti sopan santun, lapang dada, murah hati, dan sikap terpuji lainnya; ketujuh, mengajari anak-anak tentang pengetahuan yang sesuai dengan usia, derajat intelektual dan daya tangkap mereka; kedelapan, mengamalkan apa yang sudah diajarkan, mengingat ia sebagai model bagi anak-anak yang ia didik; kesembilan, harus memahami minat, bakat dan jiwa anak-anak yang dididik; kesepuluh, menanamkan keimanan ke dalam kepribadian anak, sehingga seorang anak mempunyai karakter yang terjiwai oleh nilai-nilai keimanan.

Menurut al-Ghazali yang dikutip Syamsul Kurniawan (At-Turats, Volume 3, Nomor 1, Desember, 2008, hlm. 27), anak-anak perlu dididik sehingga mempunyai sifat, tugas, dan tanggung jawab, seperti: pertama, membiasakan diri menjauh dari perbuatan keji, munkar, dan maksiat. Hal ini karena untuk mendapatkan keberkahan dan manfaat ilmu, seseorang hendaknya menjauhi perbuatan keji, munkar, dan maksiat. Perbuatan keji, munkar, dan maksiat merupakan racun bagi ilmu pengetahuan dan berseberangan dengan kemurnian 
tujuan ukhrawi; kedua, senantiasa mendekatkan diri kepada Allah Swt, yang mustahil terwujud tanpa kesadaran pentingnya menyucikan jiwa dan beribadah pada-Nya; ketiga, memusatkan perhatian terhadap ilmu yang dikaji atau dipelajarinya, serta mengurangi ketergantungan kepada masalah keduniawian; keempat, tidak menyombongkan diri dengan ilmunya, dan apalagi mendurhakai orang-orang yang mendidiknya, sebagaimana seorang pasien yang yakin dengan saran dan nasihat dokter yang merawatnya; kelima, tidak melibatkan diri dalam perdebatan, sebelum terlebih dahulu mengkaji dan memperkokoh pandangannya dengan dasar-dasar ilmu tersebut; keenam, tidak meninggalkan pelajaran, dalam rangka memperoleh ilmu yang bermanfaat. Kemudian dipelajari terus menerus dalam kesempatan lain, untuk menyempurnakan pengetahuannya atas pelajaran tersebut; ketujuh, tidak memasuki sebuah bidang ilmu dengan serentak, tetapi memelihara dengan tertib urutannya, dan memulainya dari yang terpenting.

Berdasarkan ulasan di atas, di antara yang perlu ditanamkan pada seorang anak adalah kesadaran pentingnya akhlaq al-karimah, seperti memelihara kesucian jiwa terutama dari perbuatan yang buruk atau tercela, menjauhi sifat sombong, dan sebagainya. Seorang anak juga harus dibiasakan sejak dini untuk tidak terlalu menghamba pada urusan duniawi. Kemudian, seorang anak juga hendaknya diajari belajar tuntas, dalam artian tidak berpindah pada pelajaran yang lain, sebelum pelajaran sebelumnya tuntas dipahami (Muhammad Jawwad Ridha, 1980: 25).

\section{SEBUAH TIMBANGAN}

Pemikiran al-Ghazali tentang pendidikan karakter anak berbasis akhlaq alkarimah di atas bercorak religius-sufistik. Pemikiran al-Ghazali ini masih relevan kita terapkan. Apalagi, sebagaimana dimafhumi, di tengah keadaan bangsa Indonesia yang menunjukkan gejala kemerosotan moral yang amat parah. Krisis karakter yang tengah menimpa bangsa ini seperti kanker yang terus menggerogoti sendi-sendi bangsa, mulai dari kasus maraknya narkoba, pergaulan bebas, korupsi, dan lain-lain. Semua ini mengindikasikan sedang terjadinya pergeseran ke arah ketidakpastian akan jati diri dan karakter bangsa (Syamsul Kurniawan, At-Turats, Volume 6, Nomor 1, Desember 2012, hlm. 15-16). 
Pendidikan karakter anak berbasis akhlaq al-karimah penting diberikan pada anak-anak sejak usia dini. Alasan-alasan kemerosotan moral, dekadensi kemanusiaan yang terjadi dan menjadi ciri khas abad kita, membuat kita perlu mempertimbangkan kembali bagaimana lembaga-lembaga pendidikan dapat menyumbangkan perannya bagi perbaikan akhlaq. Apalagi perbaikan akhlaq merupakan salah satu amanah dari Undang-Undang Nomor 20 tahun 2003 tentang Sistem Pendidikan Nasional, yang di antaranya bertujuan untuk mengembangkan potensi anak sehingga mempunyai kecerdasan, kepribadian dan akhlaq yang mulia. Berdasarkan ini, amanah dari Undang-Undang Nomor 20 tahun 2003 tentang Sistem Pendidikan Nasional, yaitu agar lembaga pendidikan tidak hanya bertanggungjawab mencetak insan yang cerdas, namun juga berakhlaq mulia (berakhlaq al-karimah).

Berdasarkan hasil kajian atas pemikiran al-Ghazali, diketahui dengan jelas bahwa pendidikan karakter berbasis akhlaq al-karimah bertujuan membentuk karakter positif anak yang bermuara pada pendekatan diri kepada Allah, sehingga kelak ia dapat memperoleh kebahagiaan di dunia dan di akhirat. Pemikiran alGhazali ini sejalan dengan trend integrasi ilmu dan agama, sebagaimana yang berkembang belakangan ini, di mana ilmu yang identik dengan pencapaian kebahagiaan duniawi mesti diposisikan secara mutualis dengan agama untuk pencapaian kebahagiaan ukhrawi. Beberapa tokoh yang yang ikut menyuarakan hal ini, di antaranya Ismail Raji al-Faruqi, Syed Muhammad Naquib al-Attas, Fazlur Rahman, Ziauddin Sardar, Kuntowijoyo, Azyumardi Azra, M. Amin Abdullah, Imam Suprayogo, dan lainnya (Syamsul Kurniawan, Fikrah, Volume 1, Nomor 1, Januari-Juni 2013, hlm. 142).

Al-Ghazali tidak pernah mengasumsikan bahwa pencapaian kebahagiaan dunia itu sesuatu hal yang tidak penting. Al-Ghazali hanya menggarisbawahi bahwa pencapaian kebahagiaan dunia itu hanya sebatas jalan yang mengantarkan kepada kebahagiaan akhirat yang lebih utama dan kekal. Dunia adalah ladang atau kebun untuk kebutuhan akhirat. Asumsi inilah yang mendasari pemikirannya tentang tujuan pendidikan, yang bermuara pada keinginan mendekatkan diri kepada Allah Swt (A. Syaefuddin, 2005: 143-144). Dalam Ihya' Ulumuddin, AlGhazali (2008) mengatakan, "Sesungguhnya hasil ilmu itu ialah mendekatkan diri 
kepada Allah, Tuhan semesta alam...”. Di sinilah letak pentingnya akhlaq alkarimah yang mendasari pendidikan karakter pada anak.

Modal yang mengantarkan tujuan pendidikan ini, menurut al-Ghazali adalah ilmu yang bermanfaat. Ilmu yang bermanfaat adalah ilmu yang akan mengantarkan seorang anak menjadi pribadi-pribadi yang berakhlaq mulia. Tentu saja ini tidaklah mudah, karena seperti dikatakan al-Ghazali, "mendidik anak ibarat mengukir di atas batu". Apalagi, anak, sebagaimana pendapat al-Ghazali, ibarat kertas kosong, yang menerima apapun yang dibuat padanya. Pendapat alGhazali ini rupanya menginspirasi pendapat pemikir berikutnya setelah 13 abad kemudian yaitu John Locke yang mengenalkan empirisme dan teori tabularasa. Sebagaimana al-Ghazali, John Locke juga mengasumsikan anak yang lahir sebagaimana meja lilin yang bersih (tabularasa). Perkembangan anak menurut Locke amat ditentukan oleh lingkungan pendidikannya (M. Arifin, 1991: 25; Syamsul Kurniawan, 2016: 71).

Seorang anak perlu dibiasakan berakhlaq al-karimah dan mengamalkan ilmu yang diperolehnya. Hal ini, karena sebagaimana pendapat al-Ghazali, seorang anak yang telah dididik dengan baik sehingga mempunyai kesadaran bahwa penguasaan ilmu pengetahuan bukanlah untuk meraih simpatik, pujian, sanjungan, imbalan materi, dan sebagainya, melainkan yang dilandasi keikhlasan karena mencari ridha Allah SWT. Dalam pencapaian hal ini, seorang anak perlu dididik dan diajari sejak usia dini, sehingga terbiasa berakhlaq al-karimah. Di mana hasil pendidikan ini diyakini kelak akan mengantarkan sang anak tumbuh berkembang dengan sifat dan perilaku yang mencerminkan akhlaq al-karimah.

\section{KESIMPULAN}

Pendidikan karakter dalam Islam merupakan sebuah proses membentuk akhlaq al-karimah, sehingga diharapkan akan terbentuk kepribadian dan watak yang baik, yang bertanggung jawab akan tugas yang diberikan Allah kepadanya di dunia, serta mampu menjalankan perintah-Nya dan menjauhi larangan-Nya. Karena itu dalam Islam, pendidikan karakter sama maknanya dengan pendidikan agama yang berbasis akhlak. Islam melihat pentingnya membentuk pribadi muslim yang berakhlaq mulia (akhlaq al-karimah). 
Menurut al-Ghazali, akhlaq perlu dididikkan dan diajarkan sejak usia dini, sehingga seorang anak paling tidak mengetahui tentang batas perbedaan antara perbuatan baik dan buruk, sanggup untuk melakukannya, serta dapat menilai kondisi atau keadaan akhlaqnya (apakah baik atau buruk). Berdasarkan hasil kajian atas pemikiran al-Ghazali, diketahui dengan jelas bahwa pendidikan karakter berbasis akhlaq al-karimah bertujuan membentuk karakter positif anak yang bermuara pada pendekatan diri kepada Allah, sehingga kelak ia dapat memperoleh kebahagiaan di dunia dan di akhirat. 


\section{DAFTAR PUSTAKA}

A. Syaefuddin. 2005. Percikan Pemikiran Imam al-Ghazali: Dalam Pengembangan Pendidikan Islam Berdasarkan Prinsip Alquran dan Assunnah. Bandung: Pustaka Setia.

Abdurrahman Hasan Habnakah al Maidani, 1979. Al-Akhlâq al Islâmiyyah wa Ususuhâ, Cet. I, Juz I. Damaskus: Darul Qalam.

Abu Abdirrahman al Khalil bin Ahmad al Farahidi, tth. Kitâbul 'Ain, Tahqiq: Dr. Mahdî al Makhzûmî dan Dr. Ibrâhîm as Sâmirâ'î. Juz IV. Dar dan Maktabah al Hilâl.

Abu Al-Wafa' Al-Ghanimi Al-Taftazani, 1974. Sufi dari Zaman ke Zaman. Bandung: Pustaka.

Abu Hamid Muhammad bin Muhammad al Ghazali, 1960. Al-Munqiz min alDhalal. Beirut: Maktabah al-Syaibah.

Abu Hamid Muhammad bin Muhammad al Ghazali, 1968. Ayyuhal Walad. Baghdad: Mathba'ah al-Ma'arif.

Abu Hamid Muhammad bin Muhammad al Ghazali, 2008. Ihya' Ulumuddin. Juz III. Murâja'ah: Shidqi Muhammad Jamil al 'Aththar. Beirut: Darul Fikr.

Abuddin Nata, 1997. Filsafat Pendidikan Islam. Jakarta: Wacana Ilmu.

Al-Jahizh, 1989. Tahdzîbul Akhlâq, cet. I. Darush Shahâbah lit Turâts.

Al-Tibawi, 1972. Islamic Education. London: Lucaz \& Company Ltd.

Arief Furchan dan Agus Maimun, 2005. Studi Tokoh: Metode Penelitian Mengenai Tokoh. Yogyakarta: Pustaka Pelajar.

Hasan Langgulung, Beberapa Pemikiran tentang Pendidikan Islam. Bandung: AlMaarif.

John M. Echols dan Hassan Shadily, 2006. Kamus Inggris-Indonesia. Jakarta: Gramedia.

Lorens Bagus, 2005. Kamus Filsafat. Jakarta: Gramedia.

M. Arifin, 1991. Kapita Selekta Pendidikan Islam. Jakarta: Bumi Aksara.

M. Bahri Ghazali, 1996. Konsep Ilmu Menurut al-Ghazali. Jakarta: Pedoman Ilmu Jaya.

Muhammad bin Mukarram bin Manzhûr al Afriqi al Mishri, tth. Lisânul 'Arab, Cet. 1, Juz X. Beirut: Daru Shâdir. 
Muhammad Jawwad Ridha, 1980. Al-Fikr al-Tarbawi al-Islami. Mesir: Dar alFikr al-Arabi.

Ramayulis dan Samsul Nizar, 2009. Filsafat Pendidikan Islam: Telaah Sistem Pendidikan dan Pemikiran Para Tokohnya. Jakarta: Kalam Mulia.

Syamsul Kurniawan, "Dikotomi Agama dan Ilmu dalam Sejarah Umat Islam Serta Kemungkinan Pengintegrasiannya", dalam Fikrah, Volume 1, Nomor 1, Januari-Juni 2013.

Syamsul Kurniawan, "Konsep dan Implementasi Pendidikan Karakter di Lingkungan Keluarga, Sekolah, dan Masyarakat", dalam At-Turats, Volume 6, Nomor 1, Desember 2012.

Syamsul Kurniawan, "Pendidikan Menurut Al-Ghazali", dalam At-Turats, Volume 3, Nomor 1, Desember, 2008.

Syamsul Kurniawan, 2013. Pendidikan Karakter. Yogyakarta: Arruzz

Syamsul Kurniawan, 2016. Ilmu Pendidikan Islam: Sebuah Kajian Komprehensif. Yogyakarta: Ombak.

Thâha Abdussalam Khudhair. 1997. Falsafatul Akhlâq 'inda Ibni Miskawaih. Tk: Tp.

Undang-Undang Nomor 20 tahun 2003 tentang Sistem Pendidikan Nasional. Jakarta: Sinar Grafika. 2003.

Yayasan Penerjemah Alquran, 1980. Alquran dan Terjemahannya. Madinah: Qadim al-Haramain al-Syarifain.

Yoke Suryadarma dan Ahmad Hifdzil Haq, "Pendidikan Akhlaq Menurut Imam Al-Ghazali”, dalam At-Ta'dib, Volume 10, Nomor 2, Desember 2015. 